\title{
Modification of the radioactive microsphere technique for assessment of regional blood flow to the craniofacial skeleton in the New Zealand rabbit
}

\author{
Giorgio C La Scala MD FMH ${ }^{1}$, Robert L Shenker MD ${ }^{1}$, \\ Patrick D Addison BSc MBChB MRCS ${ }^{1}$, An-Guo Zhong MD², Cho Y Pang PhD², \\ Peter C Neligan MD FRCSC ${ }^{3}$, Christopher R Forrest MD MSc FRCSC ${ }^{1}$
}

GC La Scala, RL Shenker, PD Addison, et al. Modification of the radioactive microsphere technique for assessment of regional blood flow to the craniofacial skeleton in the New Zealand rabbit. Can J Plast Surg 2002;10(1):15-19.

BACKGROUND: The radioactive microsphere technique has been used extensively for the accurate measurement of tissue blood flow in experimental animals. However, the need for carotid artery cannulation for injection of microspheres may significantly impair blood flow to the head and neck region.

OBJECTIVE: This study assessed an alternative technique of injecting microspheres directly into the left ventricle to ensure a symmetric distribution of microspheres to the head.

METHODS: Twenty-five New Zealand rabbits (seven to nine weeks of age) underwent blood flow measurement to the orbitozygomatic complex (OZC) regions bilaterally. Under general anesthesia, a sternotomy was performed and a cannula was inserted into the left ventricle. Radioactive microspheres were injected after a stabilization period of $15 \mathrm{~min}$. Blood pressure and cardiac output were measured during the procedure and the animals were sacrificed at the end of the experiment. Tissue samples were harvested bilaterally from the OZC, hemimandibles, masseter muscles and overlying skin for measurement of blood flow.

RESULTS: There was no significant difference in blood flow between the right and left side specimens. Animals were hemodynamically stable during the procedure.

CONCLUSION: Assessment of blood flow to the craniofacial region in experimental animals using radioactive microspheres may be facilitated by sternotomy and direct intracardiac injection.

Key Words: Craniofacial skeleton; Microspheres; Radioactive tracers; Regional blood flow

\footnotetext{
${ }^{1}$ Centre for Craniofacial Care and Research, Division of Plastic Surgery and ${ }^{2}$ The Research Institute, The Hospital for Sick Children, Toronto; ${ }^{3}$ Division of Plastic Surgery, University Health Network, Toronto, Ontario

Correspondence and reprints: Dr Christopher R Forrest, Centre for Craniofacial Care and Research, The Hospital for Sick Children, 5430-555

University Avenue, Toronto, Ontario M5G 1X8. Telephone 416-813-8659, fax 416-813-6637, christopher.forrest@sickkids.ca
} 


\section{Modification de la technique d'injection des microsphères radioactives pour évaluer le débit sanguin dans la région craniofaciale chez des lapins néo-zélandais}

CONTEXTE : La technique des microsphères radioactives est pratique courante pour mesurer précisément le débit sanguin tissulaire chez les animaux de laboratoire. Toutefois, le fait de cathétériser l'artère carotide pour injecter les microsphères peut altérer significativement le débit sanguin dans la région de la tête et du cou.

OBJECTIF : La présente étude vise à évaluer une nouvelle technique d'injection des microsphères administrées directement dans le ventricule gauche afin d'en permettre une répartition symétrique dans la tête.

MÉTHODE : Vingt-cinq lapins néo-zélandais, âgés de 7 à 9 semaines, ont subi une mesure bilatérale du débit sanguin dans la région du com- plexe orbito-zygomatique (COZ). Un cathéter a été introduit dans le ventricule gauche après qu'une sternotomie a été pratiquée sous anesthésie générale. A suivi l'injection de microsphères radioactives après une période de stabilisation de $15 \mathrm{~min}$. Nous avons mesuré la pression artérielle et le débit cardiaque durant l'intervention, puis euthanasié les animaux à la fin de l'expérience. Des prélèvements tissulaires ont été effectués de chaque côté du COZ, des hémimandibules, des muscles masséters et de la peau sus-jacente pour des mesures du débit sanguin.

RÉSULTATS : Nous n'avons pas relevé de différence significative du débit sanguin entre les tissus prélevés du côté droit et du côté gauche. Les animaux sont restés hémodynamiquement stables tout au long de l'intervention.

CONCLUSION : L'évaluation du débit sanguin dans la région craniofaciale chez les animaux de laboratoire à l'aide de microsphères radioactives injectées directement dans le cœur après une sternotomie peut s'avérer plus fiable que la technique usuelle d'injection.
$\mathrm{T}$ he use of radioactive microspheres for studying cardiac output and tissue blood flow was introduced by Rudolph and Heymann (1) in 1967 in a fetal sheep model. Subsequently, the technique has been applied and validated in several animal models (2-5) and has been used reliably in research laboratories to measure the blood supply to organs and tissues precisely.

The application of this technique requires three arterial access points - for blood pressure monitoring, blood sampling and microsphere injection. The right carotid artery is used for microsphere injection, given the straighter anatomical path from it to the left ventricle. The distal part of the artery is ligated at the time of cannulation, and this ligation can influence the distribution of microspheres to the ipsilateral head and neck region.

The purpose of this study was to assess a modification of this technique, allowing direct ventricular injection of the microspheres without the use of instrumentation and ligature of a carotid artery to allow undisturbed blood flow to the craniofacial skeleton.

\section{ANIMALS AND METHODS}

\section{Animal management}

Male New Zealand White rabbits (Oryctolagus cuniculus; seven to nine weeks of age; $1.65 \pm 0.25 \mathrm{~kg}$ [mean \pm SD]) were used in this study. All rabbits were housed in individual cages in a temperature-controlled $\left(22^{\circ} \mathrm{C}\right)$ and light-controlled (07:00 to 19:00) holding room, and they were each offered a commercial diet and tap water as desired. The rabbits were obtained one week before the surgery was performed to allow for acclimatization before commencing the study.

This study was reviewed and approved by the Animal Care Committee at the Hospital for Sick Children, Toronto, Ontario, and complied with the guidelines of the Canadian Council on Animal Care.

\section{Surgical technique}

Rabbits were premedicated with $0.25 \mathrm{~mL} / \mathrm{kg}$ of akmezine (the Hospital for Sick Children Laboratory Animal Service, [58.82 $\mathrm{mg} / \mathrm{mL}$ ketamine hydrochloride, $0.09 \mathrm{mg} / \mathrm{mL}$ atropine sulphate and $1.18 \mathrm{mg} / \mathrm{mL}$ acepromazine maleate all drugs from Bimeda-MTC Pharmaceuticals, Canada]), and the surgical areas were shaved.

Venous access was obtained on a marginal vein of the ear, and warmed lactated Ringer's solution was administered at $12 \mathrm{~mL} / \mathrm{kg} / \mathrm{h}$. Anesthesia was induced with phenobarbital $(25 \mathrm{mg} / \mathrm{kg}$ intravenously) and maintained with intermittent supplements of 5 to $10 \mathrm{mg} / \mathrm{kg}$ phenobarbital intravenously. Each rabbit was placed in the supine position on the operating table, and was warmed through a heating mattress and an overhead infrared lamp to prevent hypothermia. Body temperature was monitored with a rectal probe (YSI Telethermometer Model 437D [Yellow Spring Instruments Co, Inc, USA]). The airway was secured by tracheotomy, which was carried out through a vertical midline neck incision, dissecting to the trachea in the midline to avoid injury to the neck vessels. The rabbits were then positive-pressure ventilated using a pediatric Ventimeter ventilator (NARCO Air-Shields Inc, USA).

The right and left femoral arteries were exposed and cannulated with the largest possible polyethylene catheter (Intramedic PE 50 to PE160 [respectively, ID 0.58 to $0.76 \mathrm{~mm}$, OD 1.14 to $1.57 \mathrm{~mm}$ ] [Becton Dickinson and Co, USA]). On the right side, the catheter was advanced into the aorta to measure mean arterial pressure. On the left, it was inserted $2 \mathrm{~cm}$ in the femoral artery and connected to a mechanical withdrawal pump (Harvard Apparatus, Inc, USA).

Access to the heart was gained by sternotomy, which was carried out cranially from the xyphoid process. After opening the pericardial sac, a purse string 5-0 polypropylene suture (C-1 taper needle) was placed at the apex of the left ventricle. A gentle pull on this suture slightly rotated the heart and facilitated the ventricular cannulation. An overthe-needle $24 \mathrm{GA}$ catheter $(0.7 \times 19 \mathrm{~mm})$ was then inserted. For rabbits that weighed less than $1.5 \mathrm{~kg}$, the plastic catheter was shortened to $12 \mathrm{~mm}$ to avoid atrial injection of microspheres. After entering the left ventricular cavity with the needle, only the catheter was advanced in the direction of the atrium. An assistant maintained the 
catheter's position with long Jake forceps (Johnson \& Johnson, USA) while the needle was removed and the catheter was connected to minibore tubing (MED-RX Extension set [Benlan Inc, Canada]). The purse string suture was then tied, securing the catheter-minibore tubing assembly to the heart. The heart was then laid down in its original position (Figure 1).

\section{Measurement of blood flow by microspheres}

After allowing $15 \mathrm{~min}$ for stabilization, the radioactive microspheres were injected in approximately $60 \mathrm{~s}$ with a $1 \mathrm{~mL}$ syringe. The stability of mean blood pressure (considered as preinjection mean $\pm 4 \mathrm{mmHg}$ ) was monitored throughout the procedure using an electronic sphygmomanometer (Module HP 78205D [Hewlett-Packard Medical, USA]). At the same time, sample blood was withdrawn from the left femoral artery at $1.36 \mathrm{~mL} \times \mathrm{min}^{-1}$ for a minimum of $2 \mathrm{~min}$ or for at least $30 \mathrm{~s}$ after the end of the microsphere injection to allow the calculation of tissue blood flow.

The rabbits were subsequently sacrificed with a phenobarbital overdose $\left(100 \mathrm{mg} \times \mathrm{kg}^{-1}\right)$.

The following specimens were harvested from the right and left femoral arteries for radioactive analysis:

- strip of skin over the zygomatic arch

- sample of masseter muscle

- soft tissue and periosteum over the zygomatic arch

- OZC

- hemimandible

- lower pole of kidney

To make certain that no tracer was injected into the myocardium, the heart was harvested and counted in toto.

The specimens were weighed on a precision scale (Mettler Deltarange PE 360 [Mettler Instrumente AG, $\mathrm{CH}-8806$ Greifensee (ZH), Switzerland]) and subsequently underwent gamma radiation analysis (1282 Compugamma CS universal gamma counter [LKB Wallac, Finland]).

\section{Radioactive microsphere technique}

The methodology has been described previously $(4,5)$ and is summarized briefly. Fifteen micrometer diameter radioactive ${ }^{57}$ Co microspheres (NEN Life Science Products Inc, USA), rheologically similar to red blood cells, are injected in the left ventricle in the quantity of $200,000 \times \mathrm{kg}^{-1}$. The microspheres are distributed to tissues in direct proportion to blood supply, and given their sizes (larger than the capillaries), are trapped in the capillary bed in the first circulation. The use of an 'artificial' organ (a withdrawal pump connected to the left femoral artery, with a known blood flow rate) permits the easy calculation of blood flow to tis-

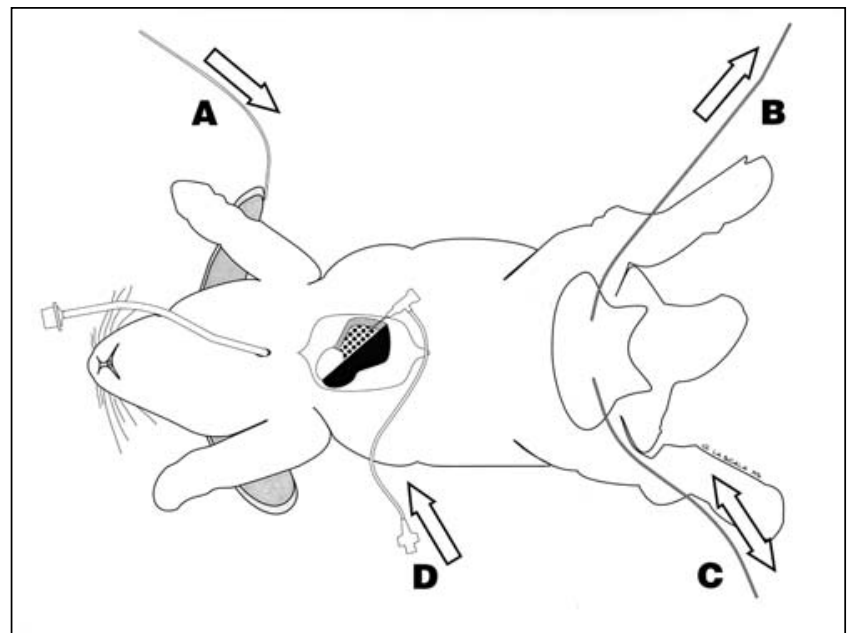

Figure 1) Rabbit prepared for blood flow study. A Left marginal venous access for intravenous fluid administration. B Left femoral artery catheter for blood withdrawal through a mechanical pump. C Right femoral artery catheter (advanced into the aorta) for continuous blood pressure monitoring. D Left ventricle cannula for radioactive microsphere injection

sues and cardiac output by comparing radioactive counts, as shown in the following formulas.

The formula used to calculate blood flow per gram of tissue is as follows.

Blood flow $(\mathrm{mL}) \times \mathrm{g}$ of tissue ${ }^{-1} \times \mathrm{min}^{-1}=$
$\frac{\text { counts from tissue } \times \text { tissue weight }(\mathrm{g})^{-1}}{\text { counts from sample }} \times$ pump rate $\left(1.36 \mathrm{~mL} \times \mathrm{min}^{-1}\right)$

The formula used to calculate cardiac output is as follows.

Cardiac output $(\mathrm{mL} / \mathrm{min})=$

$\frac{\text { total count injected }}{\text { counts from sample }} \times$ pump rate $\left(1.36 \mathrm{~mL} \times \mathrm{min}^{-1}\right)$

The 'total count injected' figure in the second formula represents the radioactivity of the microspheres that were actually injected in the left ventricle. This value was obtained by subtracting the radioactivity of the residual microspheres in the injection tubing and in the microspheres container from the total radioactivity of the microspheres, measured by standardized dilution counting.

Background average radiation count was subtracted from every count before calculation of the equations.

\section{Statistical analysis}

Results were analyzed using an IBM A20m microcomputer (International Business Machines Corporation, USA) using SPSS (SPSS Inc, USA) for Microsoft Windows (Microsoft Corporation, USA) 10.0.07 by paired $t$ test, and were considered to be significant at $\mathrm{P}<0.05$. Results were expressed as mean $\pm \mathrm{SD}$. 
TABLE 1

Results of blood flow measurements in New Zealand rabbits injected intravenously with microspheres

\begin{tabular}{|c|c|c|c|c|}
\hline \multirow[b]{2}{*}{ Tissue } & \multirow{2}{*}{$\begin{array}{l}\text { Number of } \\
\text { specimens }\end{array}$} & \multicolumn{2}{|c|}{ Blood flow $\left(\mathrm{mL} \times \mathrm{g}^{-1} \times \mathrm{min}^{-1}\right)$} & \multirow[b]{2}{*}{$\mathbf{P}$} \\
\hline & & Right side & Left side & \\
\hline Zygoma skin & 21 & $0.063 \pm 0.019$ & $0.063 \pm 0.020$ & 0.950 \\
\hline Masseter & 21 & $0.061 \pm 0.038$ & $0.057 \pm 0.035$ & 0.316 \\
\hline Perizygomatic soft tissue & 21 & $0.153 \pm 0.062$ & $0.140 \pm 0.057$ & 0.177 \\
\hline Orbitozygomatic complex & 25 & $0.069 \pm 0.045$ & $0.066 \pm 0.034$ & 0.407 \\
\hline Hemimandible & 21 & $0.094 \pm 0.035$ & $0.096 \pm 0.033$ & 0.591 \\
\hline Kidney (lower pole) & 24 & $4.142 \pm 1.527$ & $4.028 \pm 1.386$ & 0.366 \\
\hline Heart & 24 & & & $\mathrm{~N} / \mathrm{A}$ \\
\hline
\end{tabular}

N/A Not applicable

\section{RESULTS}

Core body temperature was $38.0 \pm 0.8^{\circ} \mathrm{C}$ and mean blood pressure was $70.9 \pm 13.6 \mathrm{mmHg}$. It was verified in a subset of rabbits that sternotomy did not significantly alter the blood pressure (presternotomy blood pressure was $81.0 \pm 19.9 \mathrm{mmHg}$ compared with poststernotomy blood pressure, which was $76.3 \pm 13.2 \mathrm{mmHg} ; \mathrm{P}=0.13 ; \mathrm{n}=7$ ). Cardiac output was $254 \pm 82 \mathrm{~mL} \times \mathrm{kg}^{-1} \times \min ^{-1}(\mathrm{n}=24)$.

No significant differences were detected in blood flow measurements between right and left bone samples (OZC, mandible) and soft tissue samples (periosteum and overlying soft tissue, masseter and skin) (Table 1). Renal blood flow results confirmed symmetrical systemic distribution of microspheres.

\section{DISCUSSION}

The current radioactive microsphere technique requires ligature of a carotid artery, and the presence of a catheter in the aortic arch and through the aortic valve. This catheter can partially obstruct or create turbulences in the blood flow to the aortic arch branches, especially in small-weight, experimental animals, adding a confounding factor in regional blood flow measurements. Furthermore, the polyethylene catheter that is used for injection is quite rigid and can interfere with the normal closure of the aortic valve, creating aortic insufficiency.

In a preliminary group of rabbits, we studied the distribution of the microspheres to the OZC by using a carotid artery for the insertion of the left ventricle catheter. Results showed a marked reduction of flow on the ligated carotid side (ligated - 28.2\% $\pm 13.7 \%$ and nonligated $71.8 \% \pm 13.7 \% ; \mathrm{P}=0.05 ; \mathrm{n}=4)$. An alternative route for microsphere injection is to advance the catheter through a forelimb artery or from the same femoral arteriotomy that was used to insert the cannula employed for blood pressure monitoring. However, this approach does not change the fact that a cannula is present in the aortic arch and through the aortic valve, and the correct placement of the catheter tip can be difficult in very small animals and must be helped by fluoroscopy.

The use of fluoroscopy adds further radiation exposure to the investigators who are already exposed to the gamma radiation of the microspheres. Furthermore, the time requirements for fluoroscopy-guided catheter placement in multiple study animals can interfere with the use of the $\mathrm{x}$-ray room by other research teams.

The direct injection of the tracer in the left ventricle from the heart apex does not require ligature of a carotid artery. There is no obstacle to blood outflow from the heart or in the aorta, which allows undisturbed blood flow to the whole body, with the exception of the legs, in which supplying arteries are tied.

A tracheotomy is necessary for positive pressure ventilation after the sternotomy; this is also performed more expeditiously than blind oral intubation, which is quite difficult to perform in small rabbits.

When performing the intrathoracic procedure on small rabbits, special attention should be directed to the internal thoracic artery, which is quite medial and can be injured during the sternotomy. If not recognized, this can lead to progressive hypotension and the demise of the animal. When the heart is presented for cannula insertion, the surgeon should avoid over-rotating the heart on its afferent veins, because doing so decreases preload and causes sudden hypotension. At the time of catheter insertion, the needle should be directed posteriorly toward the left atrium, and only the plastic catheter should be advanced once the needle has reached the ventricular cavity. This reduces the risk of trans-septal injection of the microspheres into the right ventricle, with resultant trapping of all the microspheres in the pulmonary circulation. By using this technique, right ventricle injection occurred only once in 91 rabbits in this study.

Sternotomy was not associated with significant changes in mean blood pressure, and this finding was confirmed in a larger sample of age- and weight-matched rabbits in which the same technique was employed (mean blood pressure before sternotomy was $67 \pm 15 \mathrm{mmHg}$ and mean blood pressure after sternotomy was $66 \pm 15 \mathrm{mmHg} ; \mathrm{P}=0.17 ; \mathrm{n}=26$ ). Cardiac output after sternotomy was comparable with data found in the literature for unanesthetized rabbits $(215 \mathrm{~mL} \times$ $\left.\mathrm{kg}^{-1} \times \min ^{-1}\right)(3)$.

The data that were obtained in this study demonstrate that direct left intraventricular injection of radioactive 
microspheres results in symmetrical distribution of the radioactive tracer to the craniofacial skeleton and overlying anatomical structures. Systemic symmetrical distribution of the microspheres is confirmed by renal blood flow that shows no statistical difference between the right and left sides $(\mathrm{P}=0.366)$.

\section{CONCLUSIONS}

Direct injection of radioactive microspheres into the left ventricle by using sternotomy affords the opportunity to

\section{REFERENCES}

1. Rudolph AM, Heymann MA. The circulation of the fetus in utero. Methods for studying distribution of blood flow, cardiac output and organ blood flow. Circ Res 1967;21:163-84

2. Rudolph AM, Heymann MA. Measurement of flow in perfused organs, using microsphere techniques. Acta Endocrinol Suppl (Copenh) 1972;158:112-27.

3. Neutze JM, Wyler F, Rudolph AM. Use of radioactive microspheres measure blood flow to the craniofacial region precisely and was not found to produce hemodynamic instability. It is hoped that this technique modification may be of use to investigators who wish to assess regional blood flow to the head and neck in laboratory animals.

ACKNOWLEDGEMENTS: The authors thank Dr Geraldine Kent and the staff of the Hospital for Sick Children Laboratory Animal Services for their expertise. to assess distribution of cardiac output in rabbits. Am J Physiol 1968;215:486-95.

4. Pang CY, Neligan P, Nakatsuka T. Assessment of microsphere technique for measurement of capillary blood flow in random skin flaps in pigs. Plast Reconstr Surg 1984;74:513-21.

5. Sasaki GH, Pang CY. Hemodynamics and viability of acute neurovascular island skin flaps in rats. Plast Reconstr Surg 1980;65:152-8. 